\title{
REPUTATION MANAGEMENT TECHNOLOGICAL TOOLS: A STAKEHOLDER APPROACH
}

\author{
VITALII SHKROMYDA, NADIYA SHKROMYDA, TARAS GNATIUK, MARIYA VASYLYUK
}

\begin{abstract}
Reputation management, as a new segment of the corporate governance system is experiencing significant dynamic impacts, particularly in the conditions of an information economy, which in the result creates a number of new challenges and, at the same time, opportunities. In the conditions of global absorption by the Internet of all spheres of human life and activity of companies the circumstances of formation and management of corporate reputation radically change. The purpose of the conducted study is an attempt to solve the issue of finding an effective tool for constructing the company's corporate reputation in the context of existing interests and expectations of its key stakeholders. It has been ground that a number of modern technological approaches and methods of reputation management for constructing corporate reputation of a company taking into account the interests of key stakeholders have been developed and tested at the theoretical and practical levels. Each of them is characterized by peculiarities of application, differently forming influence on groups of stakeholders, and also have certain advantages and disadvantages. It has been proved that the manifestation of advantages and disadvantages of each technological approach can be traced depending on the size of a company, type of activity and priorities of its key stakeholders. It has been determined that most technological approaches to reputation management are developed and focused on constructing a corporate reputation among the representatives of a consumer group of stakeholders. This is due to the strategic importance of this group of stakeholders, which most strongly expresses the level of competitiveness of a company in the market and ensures the financial stability of the business. It has been noted that the use of technological approaches in the process of constructing and maintaining a positive corporate reputation should be supported by the formation of the reputational assets of a company and the development of its corporate social responsibility. These activities require significant efforts and resources of a company. The scientific value of the conducted researches is a supplement to the theoretical and methodological basis of reputation management, in particular in the part of grounding and expediency of using technological approaches of constructing corporate reputation in accordance with the interests and expectations of key stakeholders of a company.
\end{abstract}

Keywords: reputation management, stakeholders, corporate reputation, technological approaches, reputational assets.

JEL Classification: D91, M14, M21, M31. 


\section{INTRODUCTION}

The management of modern companies has long understood that they can not afford to procrastinate and, accordingly, wait for consequences when they face the worsening or loss of reputation among a certain circle of stakeholders. In this connection, the main task of senior management of any company is to form an effective mechanism for managing reputational assets at every stage of the business life cycle, which will ultimately achieve competitive advantage in the market and, consequently, stability of functioning in the future.

Reputation management, as a relatively new segment of the corporate governance system, undergoes significant dynamic impacts, particularly in conditions of an information economy, which as a result creates a number of new challenges and opportunities at the same time. In the conditions of global absorption by the World Wide Web of all spheres of human life and activity of economic structures, the circumstances of formation and management of the corporate reputation of companies radically change. Thus, a potential consumer in free access gets acquainted with the necessary information about a company and its products, observes the reviews and makes a decisive decision on a purchase. The same concerns other stakeholder representatives who, by weighing and analyzing comprehensive information, make the right choices.

Under such conditions, we can affirm that the development and application of effective tools in the direction of constructing corporate reputation in accordance with the set goals of reputation management has strategic importance in the activity of a company and requires further development of theoretical and practical concepts in this area in accordance with existing interests of stakeholders and modern information economy.

\section{THEORETICAL BACKGROUND}

Crisis phenomena in the economy which periodically arise and their negative consequences have led to the need in solving a number of issues related to the construction of an irreproachable corporate reputation among key stakeholders as one of the important drivers of the provision of sustainable development of companies. A number of scientists, such as G. Dowling [3], C. Fombrun [4], K. Jackson [6], T. Jones [7], P. Nakra [9], H. Shamma [12], K. Tendit [14] and others, pay increased interest in finding the latest and effective approaches to constructing the corporate reputation of companies in their works. A number of researchers, such as K. Aaltonen [1], T. Donaldson [2], J. Harrison [5], J. Kaler [8], B. Neville [10], J. Post [11] and others, dedicate their work to raising questions and solving problems of effective company management in the context of interests and expectations of key stakeholders.

It should be noted that the existing scientific developments and practical recommendations concerning the development of reputation management and its implementation in the activities of companies, we believe, need theoretical addition in the part of finding effective approaches and tools to build corporate reputation taking into account the interests and expectations of key stakeholders.

\section{Research ObJective, Methodology AND DATA}

The purpose of the study is an attempt to solve the issue of finding an effective tool for constructing a company's corporate reputation in the context of existing interests and expectations of its key stakeholders. Solving this goal is possible by revealing the essence and features of the use of technological approaches in the direction of constructing corporate reputation and grouping them by effectiveness according to groups of stakeholders.

The conducted study is based on the use of general scientific methods and techniques, such as the method of generalization and systematization - in the processing of scientific papers and publications on the raised subject, the study of the nature and features of technological methods of constructing corporate reputation; as well as the abstract-logical method and the method of descriptive reflection - 
in the construction of illustrated material and the formation of author's statements and conclusions.

\section{RESUlTS AND DisCUSSION}

In the course of processing scientific publications $[6,12,14]$, it has been established that today there are two planes of management of reputational assets in reputation management, namely:

- corporate reputation management using traditional methods;

- corporate reputation management with the help or on the Internet.

The first direction of management is used in the real measurement of space and time and it foresees for this traditional management methods. In its turn, the latter direction is used in a virtual dimension of the Internet and is called Online Reputation Management or ORM in short.

Taking into account all the capabilities and limitations of online reputation management (ORM) has both significant advantages and disadvantages:

- advantage - through the Internet the cost is reduced and the time interval of formation and transmission of messages to certain recipients is reduced;

- disadvantage - the anonymity of sources of information that affect the reputation increases, and it reduces the ability to control reputational risks.

It has been determined that a number of modern technological approaches and methods of reputation management for the purpose of constructing the corporate reputation of the company [3, 6, $9,14]$ are cleared up in academic publications and practical materials. Each of them is characterized by peculiarities of application, differently forming influence on groups of stakeholders, and also have certain advantages and disadvantages. The following approaches are among the most well-known and widespread in the application.

The "Presence in public ratings" technological approach. Modern man is often interested in and asks what is best for a particular criterion or feature in a sample of existing objects. Such interest can be traced in any field of activity (political, social, professional, etc.), including economic. In this context, we can distinguish various ratings at both international and local (national, regional, thematic, etc.) levels. Such rankings are usually organized and conducted by reputable independent organizations based on the principles of transparency and justice.

Taking into account permanent interest to compiling ranking, the world's leading corporations and companies striving championship, often try to "gain" top places or ensure their presence in reputable rankings to maintain and strengthen their reputation in the market. It is known that for this purpose the specified companies allocate considerable resources, carry out various actions, fulfill a number of conditions for participation in rating. Of course, the achievement of this goal ultimately covers the costs and efforts incurred. Companies receive public recognition, secure a certain reputational status and gain the trust of others. Such reputation of a company is usually unquestionable and has a long-term effect.

Let us note that the indicated technological approach is accessible and effective for large leading companies at the international and national (regional) levels. The application of such an approach by small and medium-sized companies is unlikely and virtually unattainable.

The "Agents of trust" technological approach. A strategic approach that has long been practiced in public life and is based on the effectiveness of the well-known phrase "tell me who your friend is and I'll tell you who you are". Obvious examples of this are independent organizations, associations and professional societies. Yes, we may not know anything about a lawyer or a doctor who is defending our interest or treating us, but we trust them because they are members of relevant professional associations and are on the legal and medical register. In this case, a relevant professional association and a profile register have a reputation and, being their member, a lawyer and a doctor also acquire appropriate reputation.

A similar extrapolation can be transferred to companies that similarly build and maintain their own business reputation among stakeholders. To do this, companies create professional associations to solve joint tasks and, thus, establish at their level certain ethical standards and rules of conduct in the 
relevant market. The involvement of companies in such processes demonstrates their intention to be public, transparent and responsible.

It is positive that the indicated technological approach is available to any company, regardless of size and type of economic activity.

The "Corporate culture" technological approach. An effective strategic tool in the hands of the company's management, called to unite its staff and departments around the set goals, to ensure productive relationships between employees and motivate them to increase labor productivity. It has been proved that the provision of comfortable working conditions causes among employees respect for their profession, tolerance in interpersonal relationships with colleagues and loyalty to the company. In other words, the reputation of the company among its employees is strengthened and acquired at a higher level.

It should be noted that the indicated technological approach is gaining urgency in conditions of labor shortages in the labor market. In this context, a separate area of management is gaining popularity - HRmanagement, which aims to not only recruit staff, but also to provide appropriate conditions for employee self-development, eliminate opportunities for "burnout" and create a positive microclimate in the team. We believe that such circumstances lead to the widespread application of the approach associated with the introduction of corporate culture among companies, regardless of the type and scale of activity.

The "Corporate social responsibility" technological approach. Quite a widespread approach in developed countries and gaining popularity in other countries, where leading companies in order to ensure a high level of corporate reputation are active in social activities. This social position of a company is expressed in the harmonious coexistence and interaction with the society, as well as participation in solving or assisting in solving the most pressing social and environmental issues. To do this, companies often allocate a separate section or element on their official websites, which is devoted to the declared social responsibility and is implemented within the framework of their corporate policy. As practice shows, active social responsibility changes the attitude of a company, inspires trust and promotes business reputation among stakeholders [13].

Let us note that the indicated technological approach, in its content, is quite a costly process and requires significant resources for implementation, which ultimately makes it impossible to apply among small and medium-sized companies.

The "Crowdsourcing" technological approach. Crowd technology is a modern and, as practice shows, an effective tool for solving all kinds of business problems. The main purpose and result of the strategic approach of crowdsourcing are to find and obtain a client-partner, from the interaction with whom a company strengthens such important attributes of relationships as expectations and satisfaction.

Examples of crowdsourcing are leading companies that manufacture their own products and sell them to consumers, involving the latter in improving quality, improving technical parameters and producing new technological ideas. Also, a constant method of crowdsourcing is present in the activities of IT companies, which, involving users of their software, ask to leave suggestions for improving the company's developments. As we can see, in modern conditions, such a "public" solution to the operational and tactical activities of a company is easily solved by enabling end users to form their opinions, comments and wishes. At the same time, this approach provides an opportunity to establish feedback with customers, feel their expectations and build trust in the future.

It should be noted that when implementing reputation management in the company's activities, the indicated technological approach is quite affordable, effective and low-cost at the current level of information technology.

The "Public Leader" technological approach. It is used in companies where the "first-person" is a leader, usually charismatic, with a high level of publicity and trust among key stakeholders. Such management personally acts as the speaker of the company, often conducts presentations of their own production, opens exhibitions, and also participates directly in making both current, and strategic 
decisions of a company. In addition, most managers of this kind motivate their employees and unite them around production tasks.

It should be noted that the indicated technological approach is acceptable for both large corporations and medium and small companies, as international practice evidences. However, there is a great risk and threat that is possible in the event of a change of leadership. Under such circumstances, a company may suffer significant reputational losses and, as a result, a reduction in potential customers and employees.

The "Products and services" technological approach. There are a number of companies that in their own information flow, generate an accent for the outside world and focus their main attention on their products or services, their quality characteristics, while underestimating or not mentioning other corporate benefits. Such a strategy is often inherent in diversified companies, which have a huge set of similar and of the same kind proposals. Here food chains, hotel complexes, shopping malls, etc. should be referred to which have a specialized market segment, demonstrate many years of experience in the corresponding field and key benefits of their products or services.

The disadvantage of the indicated technological approach, we think, is its narrow trend, which is mainly aimed at consumers and clients, while ignoring the interests and expectations of other stakeholders of a company. In such circumstances, building and maintaining a corporate reputation among recent contact groups require the use of other reputational management approaches.

The "Professional staff" technological approach. It is inherent to companies that in the course of their activities use employees and officials with a high level of qualification and professionalism. Considering the personal reputation of such highly qualified specialists, the companies where they work strengthen their own reputational positions in the corresponding market. Here consulting companies, law agencies, medical clinics, IT firms, etc. should be referred to.

Let us note that the use of such a technological approach allows you to take into account the expectations and interests of several contact groups of a company, such as consumers, partners, investors, etc.

The "Achieved goals" technological approach. Quite an effective means of building and maintaining of business reputation of companies that are positioned in the developing markets. Public demonstration of the achieved goals allows companies to declare to consumers and competitors about their competitive advantages and market leadership. For example, mobile operators in the advertisements of their services like to mention multimillion number of their customers, banking institutions like to mention the size of loan portfolios and other financial indicators, car manufacturers like to mention the number of machines released from the assembly line, and so on. Messages about such corporate achievements are intended to convey to key stakeholders about the stability of the company's operations and convincing prospects for sustainable development in the future.

It is positive that the technological approach about the achieved goals is acceptable for different companies regardless of the scale and type of activity and is aimed at different contact groups.

The "Working with public opinion leaders" technological approach. It has proved itself in anticrisis management, when the loss of corporate reputation requires immediate response and actions. This approach is one of the best ways to protect and restore reputation, which involves working with public opinion leaders. Authoritative journalists, professional experts, public figures and activists who publish positive messages and smooth out reputational risks of a company are referred to here. It is worth noting that bloggers - people who create blogs (messages) in various thematic genres (educational, entertainment, development, etc.) have recently gained significant influence on public opinion, they form a circle of supporters and have a significant informational impact on them. Video bloggers are becoming especially popular.

Of course, taking into account the level of popularity and the scale of influence on society, the work with opinion leaders can afford only large companies with significant resource opportunities.

The "Maintaining the official site" technological approach. It is known that today every selfrespecting company maintains and develops its own website, through which all corporate information, key elements of activity and official announcements of the company's management are posted. The 
presence of a corporate website declares to the interested parties the legitimacy of the company's activities and serious intentions to cooperate.

The implementation of the indicated approach is carried out by SEO-specialists who perform site optimization on internal and external parameters in order to increase its position in the list of search engines. In practice, such specialists can work both as full-time employees and on conditions of outsourcing.

On the positive side, in today's modern business conditions, maintaining a corporate website does not require significant resources, which allows small and medium-sized businesses to apply the indicated technological approach for forming and maintaining their corporate reputation.

The "Favorable Internet search engine" technological approach. Compared to others, it is a very new approach, as it foresees managing company's reputation in the Internet environment. This approach is called SERM in abbreviation ("Search Engine Reputation Management"). It is observed that the concept of SERM is often identified with ORM (Online Reputation Management), where, of course, SERM is only a separate area of online reputation management, which covers a specific set of works aimed at optimizing the search engine and its results.

In general, the indicated technological approach has two main objectives:

- providing the expected results of a search, where information about the company will appear at the forefront;

- shifting negative information down of search results with the help of using various tools (publishing articles, blogs, disseminating positive opinion, etc.), in other words, "bleaching" the company's online reputation.

Solving the set tasks allows a company to offer potential stakeholders an opportunity to quickly find the necessary information about themselves, to acquaint them with positive feedback and, as a result, to construct the desired reputation profile.

The "Presence in social networks" technological approach. The development of social networks of various formats in the Internet environment has led to the creation of a separate segment of communication strategy - SMM ("Social Media Marketing"), the aim of which is to implement a set of measures for promoting a company and build relationships with representatives of online communities. At the same time, there is a lesser-known, but more accurate in its name and content, the SMP communication direction of activity ("Social Media Promotion"), i.e. establishment of intercommunication with potential consumers through social networks.

It is considered that messages that are spread on social networks, cause more confidence in products or services among consumers. This statement is explained by the effective mechanism of distribution of information and its perception based on personal connections. In other words, a company's presence on a social network means to be close to a potential consumer, to inspire selfconfidence in oneself and a positive reputation based on feedback.

Let us note that this technological approach of reputation management is quite affordable to use for building and maintaining corporate reputation.

Summing it up, it should be noted that each of the above technological approaches of reputation management is focused on a specific group of interested sides of a company's activity and it has both advantages and disadvantages in the use of each production situation. To conduct a comparative analysis of the above technological methods of reputation management in terms of key stakeholders of a company, Table 1 has been compiled, which takes into account the generalized author's list of stakeholder groups of a company.

It can be seen from the Table that most of the technological approaches in reputation management, which were considered in the study, were developed and oriented at representatives of the consumer group of stakeholders for information impact. And it's obvious. However, corporate reputation among stakeholders of this group most significantly expresses the level of competitiveness of a company in the market and ensures financial stability. Next, diffusion and external functional group, for which there is also a logical explanation are observed. At the same time, it should be noted that the approaches in 
reputation management for the formation of reputation among the representatives of a regulatory group, such as state and local authorities, regulatory agencies, etc were least developed.

\begin{tabular}{|c|c|c|c|c|c|}
\hline \multirow[b]{2}{*}{$\begin{array}{l}\text { Technological approaches to } \\
\text { reputation management }\end{array}$} & \multicolumn{5}{|c|}{ Stakeholders group } \\
\hline & 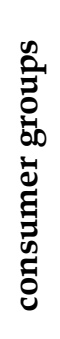 & 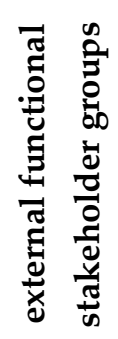 & 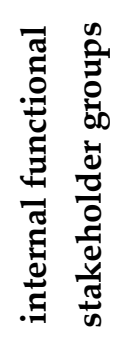 & 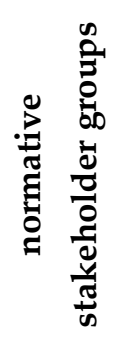 & 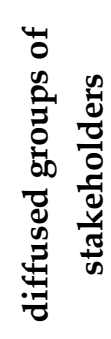 \\
\hline Presence in public ratings & + & + & + & + & + \\
\hline Trust agents & + & + & & + & + \\
\hline Corporate culture & & + & + & & \\
\hline Corporate social responsibility & + & & + & + & + \\
\hline Crowdsourcing & + & & + & & + \\
\hline Public leader & + & + & + & + & + \\
\hline Products and services & + & + & & & \\
\hline Professional staff & + & + & + & & \\
\hline Achieved goals & + & + & + & & + \\
\hline Working with public opinion leaders & + & & & & + \\
\hline Maintaining the official website & + & + & + & + & + \\
\hline Favorable search engine & + & + & & & + \\
\hline Presence in social networks & + & & & & + \\
\hline
\end{tabular}

Tab. 1. Comparison of technological approaches to reputation management in terms of key stakeholders.

* Source: developed by the authors

\section{CONCLUSIONS}

In the course of the conducted study, the following conclusions can be formed:

1. An important stage in the implementation of reputation management in a company's activities is to scan the circle of key stakeholders and study their expectations and interests, which are a priority in relation to a company and its activities. Of course, the collection of such information allows to determine the content of reputation management and build an effective "road map" for constructing corporate reputation.

2. Corporate reputation of a company is formed in different ways and means of dissemination of information. It is known that in practice there are different technological approaches to reputation management to construct the desired reputation, each of which has its own characteristics. Reasonably, the manifestation of the advantages and disadvantages of each technological approach can be traced depending on the size of a company and the priorities of its key stakeholders. It has been determined that most technological approaches to reputation management are developed and focused on constructing corporate reputation among the representatives of a consumer group of stakeholders. This is explained by strategic importance of the indicated group of stakeholders, which most strongly expresses the level of competitiveness of a company in the market and ensures the financial stability of business.

3. It has been determined that the use of technological approaches in the process of constructing and maintaining a positive corporate reputation should be supported by the formation of the 
reputational assets of a company and the development of its corporate social responsibility. The indicated activities demand painstaking daily work in the long-term period, significant efforts and resources of a company.

4. The prospect of further research is to develop a theoretical and methodological basis for the formation and development of the reputational assets of a company, which will serve as a basis for constructing corporate reputation in the context of expectations and interests of key stakeholders.

\section{REFERENCES}

[1] Aaltonen K., Jaakko K. and Tuomas O. Stakeholder salience in global projects. International journal of project management, 26 (5) (2008), 509-516. doi: 10.1016/j.ijproman.2008.05.004

[2] Donaldson T. and Preston L. The Stakeholder Theory of the Corporation: Concepts, Evidence, and Implications. The Academy of Management Review, 20 (1) (1995), 65-91. doi: 10.5465/amr.1995.9503271992

[3] Dowling G. Creating corporate reputations: Identity, image and performance. OUP Oxford, 2002.

[4] Fombrun C.J., Nielsen K. U. and Trad N. G. Saving Face for Corporate Value. Communication Director, 1 (2008), 80-84.

[5] Harrison, J.S., and Wicks, A.C. Stakeholder theory, value, and firm performance. Business ethics quarterly, 23 (1) (2013), 97-124. doi: 10.5840/beq20132314

[6] Jackson K.T. Building Reputational Capital: Strategies for Integrity and Fair Play that Improve the Bottom Line. Oxford University Press, 2004.

[7] Jones T. Instrumental stakeholder theory: A synthesis of ethics and economics. Academy of Management Review, 20 (2) (1995), 404-437. doi: 10.5465/amr.1995.9507312924

[8] Kaler J. Evaluating stakeholder theory. Journal of Business Ethics, 69 (3) (2006), 249-268.

[9] Nakra, P. Corporate Reputation Management: "CRM" with a Strategic Twist. Public Relations Quarterly, 45 (2) (2000), 35-42.

[10] Neville B., Bell, S. and Menguec B. Corporate reputation, stakeholders and the social performance financial performance relationship. European Journal of Marketing, 39 (9/10) (2005), 1184-1220. doi: 10.1108/03090560510610798

[11] Post J., Preston L. and Sachs S. Managing the extended enterprise: The new stakeholder view. California management review, 45 (1) (2002), 6-28. doi: 10.2307/41166151

[12] Shamma H.M. Toward a Comprehensive Understanding of Corporate Reputation: Concept, Measurement and Implications. International Journal of Business and Management, 7 (16) (2012), 151169. doi: 10.5539/ijbm.v7n16p151

[13] Shkromyda V., Gnatiuk T. and Shkromyda N. Evaluation of Indexes of Dynamism of Corporate Reputation in Conditions of Behavioral Economy. Corporate Reputation Review, (2021). doi: 10.1057/s41299-021-00113-9

[14] Tendit K. Fundamentals of reputation management. Komsomolsk-on-Amur, 2013. (in Russian)

Address: Vitalii Shkromyda, Nadiya Shkromyda, Taras Gnatiuk, Mariya Vasylyuk. Vasyl Stefanyk Precarpathian National University, 57, Shevchenko Str., Ivano-Frankivsk, 76018, Ukraine.

E-mail: vitaliy.shkromyda@pnu.edu.ua, nadiya.shkromyda@pnu.edu.ua, taras.gnatiuk@pnu.edu.ua, mariya.vasyliuk@pnu.edu.ua.

Received: September 15, 2021; revised: October 22, 2021. 
Шкромида Віталій, Шкромида Надія, Гнатюк Тарас, Василюк Марія. Технологічний інструментарій репутаційного менеджменту: підхід зацікавлених сторін. Журнал Прикарпатського університету імені Василя Стефаника, 8 (3) (2021), 97-105.

Репутаційний менеджмент, як новий сегмент системи корпоративного управління, зазнає суттевих динамічних впдивів, зокрема в умовах інформаційної економіки, що у підсумку породжує ряд нових викликів та, водночас, можливостей. В умовах глобального погдинання всесвітньою мережею Інтернет всіх сфер життедіяльності дюдини та діядьності компаній докорінно змінюються обставини формування і управління корпоративною репутацією. Метою проведеного дослідження $е$ спроба вирішення питання щодо пошуку дієвого інструментарію конструювання корпоративної репутації компанії у контексті існуючих інтересів та очікувань її кдючових стейкхолдерів.

Обгрунтовано, для конструювання корпоративної репутації компанії з врахуванням інтересів кдючових стейкхолдерів на теоретичному і практичному рівнях розроблено та апробовано ряд сучасних технодогічних підходів і прийомів репутаційного менеджменту. Кожен 3 них характеризується особливостями застосування, по-різному формують вплив на групи стейкхолдерів, а також мають певні переваги і недоліки. Доведено, прояв переваг та недоліків кожного технологічного підходу простежується в залежності від розмірів компанії, виду діяльності та пріоритетів їі кдючових стейкходдерів. Визначено, найбільше технологічних підходів репутаційного менеджменту розвинуто та зорієнтовано для конструювання корпоративної репутації серед представників споживацької групи стейкходдерів. Це пояснюється стратегічною важдивістю вказаної групи стейкхолдерів, яка найбільш вагомо виражає рівень конкурентоспроможності компанії на ринку та забезпечує фінансову стійкість бізнесу. Відзначено, використання технологічних підходів у процесі конструювання i підтримки позитивної корпоративної репутації повинне підтримуватися формуванням репутаційних активів компанії та розвитком іiі корпоративної соціальної відповідальності. Зазначені заходи потребують значних зусиль та ресурсів компанії.

Науковою цінністю проведених досліджень є доповнення теоретико-метододогічної основи репутаційного менеджменту, зокрема в частині обгрунтування і доцільності застосування технологічних підходів конструювання корпоративної репутації відповідно до інтересів та очікувань кдючових стейкхолдерів компанії.

Кдючові слова: репутаційний менеджмент, стейкхолдери, корпоративна репутація, технологічні підходи, репутаційні активи. 